https://doi.org/10.46344/JBINO.2020.v09i04.26

\title{
ENCOURAGING NUTRITIONAL DIET OF CAJANUS CAJAN MAY SIGNIFICANTLY REDUCE SICKLE CELL ANAEMIA
}

'HOBSON Rudof, 1ADJENE Josiah Obaghwarhievwo and 'CHIME Helen Ego

'Department of Public and Community Health Sciences, College of Health Sciences, Novena University, Ogume, Delta State, Nigeria.

Email: osgiedeprof@yahoo.com

\begin{abstract}
Sickle Cell Anaemia SCA is the commonest hemoglobinopathy that ravages most part of the world, particularly Nigeria. First-line clinical management of SCA uses hydroxyurea, folic acid, amino acids supplementation, penicillinprophylaxis, and antimalarial prophylaxis to manage the condition and blood transfusions to stabilize the patient's hemoglobin level. These are quite expensive and have attendant risk factors. However, a bright ray of hope involving research into anti-sickling properties of locally available medicinal plants like Cajanus cajan. In this study, we investigated the effect of dry seeds of Cajanus cajan in a cohort of 37 patients attending sickle cell clinic in Central Hospital Kwale and Ughelli by encouraging their consumption of Cajanus cajan after overnight soaking and preparation. While this lasted, their packed cell volume (PCV), frequency of pain crisis, and frequency of admission were monitored, while comparing these parameters with previous hospital records of the same subjects prior to commencement of the study. Our results proved that Cajanus cajan significantly decreased the frequency of bone crisis and hospital admission among the patients, averaging 1.95 and 0.57 respectively. Result (differences in means using student t-test) also returned a statistically significant improvement (at $\mathrm{p}<0.05$ ) in the steady state of PCV values for SCA sufferers from an average of 22.16 to 24.32., suggestive that a mean consumption rate of 3 meals per week is most likely acceptable with minimal side effects. Thus, it is recommended that the burden of sickle cell anaemia be significantly reduced by encouraging a nutritional (sickle cell) diet of Cajanus cajan.
\end{abstract}

Keywords: Anaemia, Sickle cell, Cajanus cajan, Nutrition 


\section{Introduction}

Sickle cell disease (SCD) is a monogenic public health ailment that affects millions of people across the globe. It is caused by an A-to-T point mutation in the $\beta$-globin of the human gene that leads to the production of abnormal haemoglobin called HbS [1, 2]. The gene defect is a single nucleotide mutation single-nucleotide polymorphism (GAG codon changing to GTG) of the $\beta$ globin gene, which results in glutamic acid (E/Glu) being substituted by valine ( $V / \mathrm{Val}$ ) at position 6 , hence it can be said that the key missing component in sickle cell disease is glutamic acid, glutamic acid is a non-essential amino acid hence the body can produce it however with the defect of haemoglobin it's production is compromised [3]. Glutamine is a conditionally essential amino acid, meaning that although the body normally makes sufficient amounts, at times of stress the body's need for glutamine increases, and in such instances, it also relies on dietary glutamine to meet this demand [4].

Cajanus cajan is said to be the $6^{\text {th }}$ most important legume in the world with various nutritional and environmental properties [5]. One of which is the very high level of glutamic acid, therefore, it is thought that the consumption of Cajanus cajan can provide the necessary level of glutamate and hence lead to a reduction in sickle cell crises and the overall global burden of the disease [6].

The greatest burden of SCA is reportedly in sub-Saharan Africa (SSA), where $75 \%$ of the 300,000 global births of affected children live and estimates suggest that $50-80 \%$ of these patients will die before adulthood [7, 8], majority of these deaths are in the under-five age group. The morbidity of SCA is enormous and includes embolic strokes, vaso occlusive crises, anaemia, splenic sequestrations, acute chest syndrome etc. Treatment is mainly symptomatic and management of complications. Bone marrow transplantation shows some potential in providing a cure however, it has several complications and a high mortality rate.

Until 2007 Hydroxyl urea has been the de facto drug approved by the US Food and Drug administration agency (FDA) for the treatment of sickle cell disease. The side effects of hydroxyurea are one of the most important concerns. Since some experiments reported several adverse events in patients treated with Hydroxylurea, indicated dermatologic (39.28\%), neurologic (23.2\%), gastrointestinal (17.5\%) and hematologic $(10.71 \%)$ events in patients with thalassemia and sickle cell disease [9].

In 2007, L-Glutamate was approved by the US FDA for the treatment of sickle cell after a phase III trial. It was found to have an ameliorating effect on sickle cell patients with minimal side effects. Pigeon peas (Cajanus cajan) is a locally available and cheap legume with a high amount of glutamate and folic acid, as well as vitamins, minerals, fibres and other amino acids, therefore the potential to reduce the frequency of crises, morbidity and mortality of sickle cell disease $[9,10]$. It can be incorporated into the diet of patients hence compliance will be higher 
than when patients are compelled to take medications. Side effects will also be limited since it is a natural food.

\section{Aim of Study}

This study assessed the ameliorating effect(s) and nutritional value of pigeon peas (Cajanus cajan) in the management of sickle cell disease. Specifically, the study;

i. Determined the lowering effect of cajanus cajan on the rate of hospital admission of sickle cell disease sufferers.

ii. Investigated if consumption of Cajanus cajan can help to increase the Packed Cell Volume of sickle cell patients.

iii. Examined the relationship between Cajanus cajan consumption rate and the reduction in the number/frequency of crises in sickle cell subjects.

\section{Materials and Method}

\section{Study Design}

Study was a retrospective cohort study looking at the sickle cell clinic at Kwale Central Hospital and Ughelli Central Hospital since their inception in Delta State, Nigeria. The study was also of the quasi-experimental design as pigeon peas (Cajanus cajanus) was introduced to the sickle cell patients that made up the cohort. The Control group comprised of subjects within the first three years from inception to commencement of the study, there was also a pre-recorded pretest and post-test of their Packed Cell Volume(PCV) records and their frequency of hospital admissions and frequency of crises.

\section{Scope of Study}

Study was conducted in Kwale Central Hospital and Ughelli Central Hospital of Delta State, Nigeria. The study was limited primarily to patients attending sickle cell clinic in the aforementioned hospitals in an attempt to boost the sample size

\section{Study Population}

All patients with sickle cell disease attending in Central Hospital Kwale and Central Hospital Ughelli, including those who attended the general outpatient clinic and those that attended the sickle cell clinic.

\section{Sample Size}

All patients attending the sickle cell clinic who agreed to partake in the study, due to the small size of the study population.

\section{Sampling Technique}

Purposive sampling was used as only patients who were willing and available during the time of study were co-opted into the study.

\section{Exclusion Criteria}

The study excluded patients less than five years old, those unwilling to participate in the study as well as all those who started the clinic less than two years ago.

\section{Inclusion Criteria}


All patients attending the clinic in the last four years, and agreed to be part of the research

\section{Method and Instrument of Data Collection Research instruments}

Hospital data was used for the study. We used data from the sickle cell clinic register, in patient register, and PCV records from their files over the past four years of commencement of the sickle cell clinic. The first three years before the introduction of the pigeon peas served as the control. And this was compared to the first year of taking the pigeon peas. Participants and their parents where counselled on the specific objectives of the study and shown a sample of the pigeon pea and encouraged to consume as frequently as possible while keeping a weekly record. These record were collated monthly when they came for their clinic. At every monthly clinic a packed cell volume (PCV) was obtained to establish the stable state PCV. The stable state PCV is the PCV of the patient when there is no illness. In-patient records where used to obtain the number of bone pain crises either necessitating admission or outpatient care and the number of admissions due to other illness. The severity of painful crises could not be objectively ascertained

\section{Reliability of Instrument}

The reliability index was determined using Cronbach's alpha test of internal consistency (SPSS Version 22)

\section{Validity of Instrument}

The validity was provided by hospital records.

\section{Ethical Consideration}

Informed consents were taken from patients and their parents/care givers where applicable.

Ethical approval was also gotten from the Delta State Ministry of Health.

\section{Method for Data Analysis}

Data was manually selected and coded for analysis using statistical package for social science (SPSS) version 21. It was summarized using descriptive statistical and chi square test of association between categorical variables.

\section{Results}

Table I: Distribution of Sickle Cell Anaemia Sufferers by Age and Gender

\begin{tabular}{l|c|c|c|c|c|cc|c|c|}
\cline { 2 - 9 } S/N & \multirow{2}{*}{ AGE } & \multirow{2}{*}{ SEX } & $\begin{array}{c}\text { FREQ OF } \\
\text { CONSUMPTION }\end{array}$ & \multicolumn{2}{c|}{$\begin{array}{c}\text { FREQ OF BONE } \\
\text { CRISES/YEAR }\end{array}$} & \multicolumn{2}{c|}{$\begin{array}{c}\text { STABLE STATE } \\
\text { PCV }\end{array}$} & \multicolumn{2}{c|}{$\begin{array}{c}\text { FREQ OF } \\
\text { ADMISION }\end{array}$} \\
\cline { 3 - 9 } & & & MEALS/WEEK & BEFORE & AFTER & BEFORE & AFTER & BEFORE & AFTER \\
\hline $\mathbf{1}$ & 14 & M & 4 & 3 & 1 & 24 & 27 & 3 & 1 \\
$\mathbf{2}$ & 8 & F & 2 & 1 & NIL & 26 & 27 & 1 & NIL \\
$\mathbf{3}$ & 15 & F & 4 & 1 & NIL & 23 & 26 & 1 & NIL \\
$\mathbf{4}$ & 18 & F & 4 & NIL & NIL & 27 & 30 & NIL & NIL \\
$\mathbf{5}$ & 7 & M & 2 & 3 & 1 & 24 & 25 & 3 & 1 \\
$\mathbf{6}$ & 11 & F & 2 & 3 & 1 & 25 & 26 & 3 & 1
\end{tabular}

2020 July Edition | www.jbino.com | Innovative Association 


\begin{tabular}{|c|c|c|c|c|c|c|c|c|c|}
\hline 7 & 12 & M & 3 & 2 & NIL & 23 & 25 & 2 & NIL \\
\hline 8 & 17 & $\mathrm{M}$ & 3 & 3 & 1 & 20 & 22 & 3 & 1 \\
\hline 9 & 5 & $\mathrm{~F}$ & 3 & 1 & NIL & 24 & 26 & 1 & NIL \\
\hline 10 & 8 & $\mathrm{~F}$ & 3 & 2 & NIL & 21 & 23 & 2 & NIL \\
\hline 11 & 8 & $\mathrm{~F}$ & 2 & 3 & 1 & 19 & 20 & 3 & 1 \\
\hline 12 & 5 & M & 3 & 3 & 1 & 18 & 20 & 3 & 1 \\
\hline 13 & 21 & $\mathrm{M}$ & 3 & 3 & 1 & 22 & 24 & 3 & 1 \\
\hline 14 & 11 & $\mathrm{~F}$ & 4 & 1 & NIL & 25 & 28 & 1 & NIL \\
\hline 15 & 24 & F & 3 & 3 & 1 & 23 & 25 & 3 & 1 \\
\hline 16 & 15 & $\mathrm{~F}$ & 4 & 2 & 1 & 21 & 24 & 2 & 1 \\
\hline 17 & 9 & $\mathrm{~F}$ & 4 & 3 & 1 & 24 & 27 & 3 & 1 \\
\hline 18 & 14 & $\mathrm{M}$ & 3 & 2 & 1 & 20 & 21 & 2 & 1 \\
\hline 19 & $3+$ & $\mathrm{M}$ & 3 & 1 & NIL & 20 & 22 & 1 & NIL \\
\hline 20 & 17 & $\mathrm{~F}$ & 3 & NIL & NIL & 26 & 28 & NIL & NIL \\
\hline 21 & 14 & F & 2 & 1 & 1 & 19 & 20 & 1 & 1 \\
\hline 22 & 17 & $\mathrm{~F}$ & 2 & 2 & 1 & 18 & 19 & 2 & 1 \\
\hline 23 & 7 & $\mathrm{~F}$ & 2 & 2 & 1 & 19 & 20 & 2 & 1 \\
\hline 24 & 7 & $\mathrm{M}$ & 3 & 2 & NIL & 18 & 21 & 2 & NIL \\
\hline 25 & 8 & $\mathrm{M}$ & 4 & 2 & NIL & 20 & 23 & 2 & NIL \\
\hline 26 & 22 & $\mathrm{M}$ & 3 & 2 & 1 & 21 & 23 & 2 & 1 \\
\hline 27 & 21 & $\mathrm{M}$ & 4 & NIL & NIL & 27 & 30 & NIL & NIL \\
\hline 28 & 25 & $\mathrm{~F}$ & 4 & 2 & 1 & 23 & 26 & 2 & 1 \\
\hline 29 & 4 & $\mathrm{M}$ & & & NIL & 20 & 22 & 2 & NIL \\
\hline 30 & 20 & $\mathrm{M}$ & 3 & 2 & 1 & 22 & 25 & 2 & 1 \\
\hline 31 & 8 & $\mathrm{~F}$ & 2 & 3 & 1 & 20 & 21 & 3 & 1 \\
\hline 32 & 15 & $\mathrm{~F}$ & 3 & 1 & NIL & 23 & 25 & 1 & NIL \\
\hline 33 & 6 & M & 4 & 2 & NIL & 22 & 25 & & NIL \\
\hline 34 & 11 & 171 & & 3 & 1 & 23 & 26 & & 1 \\
\hline 35 & 12 & $\mathrm{M}$ & 4 & 2 & NIL & 26 & 29 & 2 & NIL \\
\hline 36 & 10 & $\mathrm{~F}$ & 4 & 2 & 1 & 20 & 23 & 2 & 1 \\
\hline 37 & 20 & $\mathrm{M}$ & 3 & 2 & 1 & 24 & 26 & 2 & 1 \\
\hline
\end{tabular}

Above result shows the demography of the sickle cell anemia patients used in this study. From the result, most of the patients were female, while very few were males.

Table II: Percentage Distribution by Gender of SCA Patients

\begin{tabular}{ccc}
\hline Gender & Frequency & Percent \\
\hline Male & 18 & $48 \%$ \\
Female & 19 & $52 \%$ \\
Total & 37 & $100 \%$
\end{tabular}

Table III: Percentage Distribution by Age of SCA Patients

2020 July Edition | www.jbino.com | Innovative Association 


\begin{tabular}{c|ccc}
\hline \multicolumn{2}{c}{ N } & Mean & Std. Deviation \\
\hline Age of patients & Male & 12.44 & \\
& Female & 12.89 & \\
Total & 37 & 12.67 & 5.98 \\
\hline
\end{tabular}

Table IV: Meal of pigeon peas per week

\begin{tabular}{|c|c|c|}
\hline $\begin{array}{c}\text { Meal of Pigeon } \\
\text { peas per week }\end{array}$ & $\mathbf{N}$ & $\mathbf{\%}$ \\
\hline 2 & 8 & 21.6 \\
\hline 3 & 17 & 45.9 \\
\hline 4 & 12 & 32.4 \\
\hline TOTAL & 37 & 100.0 \\
\hline
\end{tabular}

From tables II, III and IV (above), 18(24.3\%) (Table 4.01). The table also shows that, the average age of the patients is approximately $12.7 y$ rs, while their ages Range from 3yrs to 25yrs. On the number of meals per week, Table IV shows that $21.6 \%$ of the patients take pigeon peas 2 times in a week; $32.4 \%$ of them take it 4 times in a week, while most of the SCA patients (45.9\%) take it 3 times in a week.

Table V: Sample T-test between the Frequency of hospital Admission of Patients before and after the consumption of Pigeon Peas

\begin{tabular}{|c|c|c|c|c|c|c|c|c|c|c|}
\hline & & & & \multicolumn{4}{|c|}{ Paired Differences } & \multicolumn{3}{|c|}{ t-test statistics } \\
\hline Time & $\mathrm{N}$ & Mean & SD & Mean & SD & $\mathrm{Cl}$ (lower) & $\mathrm{Cl}$ (upper) & $\mathrm{T}$ & df & $\mathrm{P}$ \\
\hline Before & 37 & 1.95 & 0.91 & & 2 & & & & & \\
\hline After & 37 & 0.57 & 0.50 & & 0.00 & $1.1 J$ & 1.01 & 12.31 & 30 & 0.000 \\
\hline
\end{tabular}

Table $V$ shows that there was a significant difference in the frequency of admission before (1.95 \pm 0.91$)$ and after $(0.57 \pm 0.50)$ the consumption of Pigeon Peas $(d f=36), t=12.31, \rho=0.00)$. the result shows that before the intervention, the sickle cell patients are admitted on the average of twice, but after the intervention, they barely were admitted in the hospital. The result therefore shows that the consumption of pigeon peas significantly reduces the rate of admission of sickle cell patients.

Table VI: Sample T-test between the Steady State PCV of Patients before and after the consumption of Pigeon Peas

\begin{tabular}{|c|c|c|c|c|c|c|c|c|c|c|}
\hline & & & & \multicolumn{4}{|c|}{ Paired Differences } & \multicolumn{3}{c|}{ t-test statistics } \\
\hline Time & $\mathrm{N}$ & Mean & SD & Mean & SD & $\begin{array}{c}\mathrm{Cl} \\
\text { (lower) }\end{array}$ & $\begin{array}{c}\mathrm{Cl} \\
\text { (upper) }\end{array}$ & $\mathrm{T}$ & $\mathrm{df}$ & $\mathrm{P}$ \\
\hline Before & 37 & 22.16 & 2.62 & -2.16 & 0.80 & -2.43 & -1.90 & -16.44 & 36 & 0.000 \\
\hline
\end{tabular}




\begin{tabular}{|l|l|l|l|l|l|l|l|l|l|l|}
\hline After & 37 & 24.32 & 2.95 & & & & & & & \\
\hline
\end{tabular}

Above table shows that there was a significant difference in the Steady State PCV before (22.16 \pm 2.62$)$ and after (24.32 \pm 9.95$)$ the consumption of Pigeon Peas $(t(36)=-16.44, \rho=0.00)$. the result shows that before the intervention, the mean Steady State PCV of the participants is 22.16, but after the intervention, the Steady State PCV increased to 24.32, with a mean difference of -2.16. The result therefore shows that the consumption of pigeon peas increases the Steady State PCV of sickle cell patients. (the negative sign is a result of the lower value in the before intervention score which is subtracting a higher value of the after intervention score)

Table VII: t-test and frequency of Bone Pains Crisis of Patients before and after the consumption of Pigeon Peas

\begin{tabular}{|c|c|c|c|c|c|c|c|c|c|c|}
\hline & & & & \multicolumn{4}{|c|}{ Paired Differences } & \multicolumn{3}{|c|}{ t-test statistics } \\
\hline Time & $\mathrm{N}$ & Mean & $\mathrm{SD}$ & Mean & $\mathrm{SD}$ & $\mathrm{Cl}$ (lower) & $\mathrm{Cl}$ (upper) & $\mathrm{T}$ & $\mathrm{df}$ & $\mathrm{P}$ \\
\hline Before & 37 & 1.95 & 0.91 & \multirow{2}{*}{1.38} & \multirow{2}{*}{0.68} & \multirow{2}{*}{1.15} & \multirow{2}{*}{1.61} & \multirow{2}{*}{12.31} & \multirow{2}{*}{36} & \multirow{2}{*}{0.000} \\
\hline After & 37 & .57 & 0.50 & & & & & & & \\
\hline
\end{tabular}

Table VII shows that there was a significant difference in the frequency of Bone Pains Crisis before (1.95 \pm 0.91$)$ and $(0.57 \pm 0.50)$ after the consumption of Pigeon Peas $(t(36)=12.31, \rho=0.00)$. the result shows that before the intervention, the sickle cell patients had an average of bone pain crisis twice a year, but after the intervention, the bone pain crisis reduced to an average of 0.6 per within a year. The result therefore shows that the consumption of pigeon peas reduces the frequency of bone pain crisis of sickle cell patients.

\section{Discussion}

Pigeon peas (Cajanus cajan) is a locally available and cheap legume with a high amount of glutamate and folic acid, as well as vitamins, minerals, fibres and other amino acids, therefore the potential to reduce the frequency of crises, morbidity and mortality of sickle cell disease. It can be inco-operated into the diet of patients hence compliance will be higher than when patients are compelled to take medications. In this study, the ameliorating effect(s) and nutritional value of pigeon peas in the management of sickle cell disease was investigated. From our study, the mean age of the participants was $12.67 \pm 5.98$ years with a slightly lower male to female ratio of 18:19. The males were also slightly younger than the females with a mean age of 12.44 years compared to 12.89 years. The mean consumption was 3 times weekly with 8 of them eating twice a week, 17 eating 3 times weekly and 12 eating 4 times weekly.

The finding on frequency of admission per year of patients before and after one year of consuming pigeon peas showed a statistically significant decrease from 1.95 admission per year 1.95 \pm 0.91 $(p=<0.05)$ before to less than one per year i.e. $0.57 \pm 0.50(p=<0.05)$ after. When compared to results of 4.75 before treatment to 2.25 with a confidence interval of $>95 \%$ after treatment with use hydroxyurea [11]. One of the hallmarks of ino.com I Innovative Association 
sickle cell disease is anaemia due to the shortened lifespan of HbS (40-50days) compared to an average of 120 days for $\mathrm{HbA}$.

For this study, the steady state PCV was taken as the PCV level when the patients are free of illness for 2 weeks and was usually taken when the patient came for routine clinics which was monthly, with most patients having over six visits a year. The study showed a statistically significant increase in the steady state PCV from a mean of $22.16 \pm 2.62(p=<0.05)$, to $24.32 \pm$ 2.95 after taking pigeon peas meals for just one year. This is comparable to a study using hydroxyurea, were Hemoglobin ( $/ \mathrm{dL})$ increased from $8.15 \pm 1.30$ to $8.77 \pm 1.240 p=.01$ [12]. The steady state PCV is also in keeping with a report that most patients $(57.1 \%)$ had hemoglobin between $7-10 \mathrm{~g} / \mathrm{dl}$ and 63.3\% had packed cell volume between $20-30 \%$. Only $11.2 \%$ had hemoglobin greater than $10 \mathrm{~g} / \mathrm{dl}$ and $12.2 \%$ had packed cell volume greater than $30 \%$. While 31 (31.6\%) had hemoglobin less than $7 \mathrm{~g} / \mathrm{dl}$ and 24 (24.5\%) had packed cell volume between 13-20\%. Mean $\mathrm{Hb}$ level in males was $8.14 \pm 1.54$ and in females was $7.73 \pm 1.45(p=0.8)$. The mean $P C V$ in males was $25.1 \pm 4.9$ and in females was $23.9 \pm 4.6(p=0.6)[2,13]$.

The most dramatic presentation of Sickle Cell Anaemia is the Bone pain crisis which affects the back, femur, tibia., digits, abdomen, etc. Vaso-occlusive pain episodes are the hallmark of sickle cell disease that is most commonly manifested by bone pain. Individuals with SCD experience recurrent pain episodes, and up to $30 \%$ of patients report daily symptoms. Sickle cell disease pain may last for hours to days, and some SCD individuals are never completely pain-free [14].

The findings showed a mean of $1.95 \pm 0.91 \quad(p=\quad<0.05)$, before commencement of the study reducing to $0.57 \pm 0.501 \quad(p=<0.05)$, after a year of consuming pigeon peas, a $71 \%$ reduction in the median number of pains per year. This result was even more significant than a study done in a multicentre study using hydroxyurea in sickle cell anaemia, which enrolled patients with $S C D \geq 18$ years of age, hydroxyurea was associated with a $44 \%$ reduction in the median number of pain episodes per year compared to the placebo (4.5 vs. $2.5, P<0.001)$ as well as a reduction in the median number of pain episodes requiring hospitalization (2.4 vs. 1.0 per year, $P<0.001$ ) [15].

These findings are also similar to that of Akinsulie, Temiye, Akanmu and Lesi (2005) who in their study on 100 sickle cell patients that were given the extract of Cajanus cajan and monitored for six months found that extracts of pigeon pea reduced the bone pains of sickle cell patients that were sampled [16]

Cajanus cajan has also been found to be potent and relatively safe for use in preventing sickle cell crisis [17]. Fernandes (2017) reported that the percentage of sickled cells before the laboratory experiments was $91.6 \%$, but that decreased with treatment with $C$. cajan seed (41.7\%), C. cajan leaf $(32.8 \%)$, in a study on laboratory animals [18]. Cordovil (2015), reported that in Brazil, detailed studies with pigeon peas chemical-biological may clarify the 2020 July Edition | www.jbino.com | Innovative Association 
mechanisms by which the inhibition of sickling of red blood cells occurs, reducing oxidative stress and thus helping treating people affected by this disease [19].

\section{Conclusion}

Eating of pigeon peas (Cajanus cajan), at a rate of three meals per week over a period of one year by thirty seven patients with a mean age of 12.67yrs attending sickle cell clinic in Central Hospital kwale and Central Hospital Ughelli and using the first three years of not eating the pigeon peas while attending the sickle cell clinic as a control, showed a statistically significant ameliorating effect on the steady state PCV, number of bone crises and number of hospital admissions in both males and females and was generally well tolerated. The high level of Glutamate and folic acid may play a role in these ameliorating effects of pigeon peas however other nutrients may also be responsible

\section{References}

Aidoo M, Terlouw DJ, Kolczak MS, McElroy PD, ter Kuile FO, Kariuki S, Nahlen BL, Lal AA, Udhayakumar V (2002) Protective effects of the sickle cell gene against malaria morbidity and mortality. Lancet., 359: 1311-1312.

Akinsegun A, Adedoyin D, Adewumi A, Olajumoke $O$, Adebola $P$, Osunkalu V, Arogundade $O$, and Adelekan $O$ (2012) Steady state hemoglobin concentrationand packed cell volume in homozygous sickle cell disease patients in Lagos, Nigeria: Caspian J Intern Med. Spring; 3(2): 405-409.

Danaee, A., Inusa, B., Howard, J., KesseAdu, R., Robinson, S. (2014). hyperhaemolysis in patients with haemoglobinopathies: A single centre experience: 229. Br. J. Haematol. 165, 96.

Akinsulie A.O, Temiye E.O, Akanmu A.S Lesi F.E.A, Whyte C.O (2005). Clinical Evaluation of Extract of Cajanus cajan (Ciklavit®) in Sickle Cell Anaemia Journal of Tropical Pediatrics, Volume 51, Issue 4, Pages 200-205

Jaiswal D, Rai PK, Kumar A, Watal G (2008). Study of glycemic profile of Cajanus cajan leaves in experimental rats. Indian J Clin Biochem. 2008; 23:16770.

Luo QF, Sun L, Si JY, Chen DH (2008). Hypocholesterolemic effect of stilbenes containing extract fraction from Cajanus cajan on diet induced hyper cholesterolemia in mice. Phytomedicine.; 15:932-9.

Williams TN, Mwangi TW, Wambua $S$, Alexander ND, Kortok M, Snow RW, Marsh K: 2005 Sickle cell trait and the risk of Plasmodium falciparum malaria and other childhood diseases. J Infect Dis., 192: 178-186.

Winter W P. (1986) Hemoglobin variants in human populations.CRC Press, Boca Raton, Vol 1 and 2, 
Dilipkumar P, Pragya M,Neetu $S$, Ashoke K. (2011), Biological activities and medicinal properties of cajanu cajan (L) Millisp j Adv Pharm Technol Res 2(4): 207214

Angastiniotis, M., Modell, B. (1998). Global epidemiology of hemoglobin disorders. Annals of the New York Academy of Sciences. 850(1):251-69.

Ding, C., Chiu, R.W., Lau, T.K., Leung, T.N., Chan, L.C., Chan, A.Y., (2004). MS analysis of single-nucleotide differences in circulating nucleic acids: application to non-invasive prenatal diagnosis. Proceedings of the National Academy of Sciences of the United States of America. 101 (29):10762-10767.

Ghasemi A, Keikhaei B, Ghodsi R. (2014). Side effects of hydroxyurea in patients with Thalassemia major and thalassemia intermedia and sickle cell anemia. Iran J Ped

Habara, A., Steinberg, (2016). M.H. Minireview: Genetic basis of heterogeneity and severity in sickle cell disease. Exp. Biol. Med. 241, 689-696.

Smith WR, Penberthy LT, Bovbjerg VE, McClish DK, Roberts JD, Dahman B, Roseff SD. (2008): Daily assessment of pain in adults with sickle cell disease. Annals of Internal Medicine. 148(2):94-101

Charache S, Terrin ML, Moore RD, Dover GJ, McMahon RP, Barton FB, (1995): Design of the multicenter study of hydroxyurea in sickle cell anemia. Investigators of the Multicenter Study of Hydroxyurea. Control Clin Trials. 16:432-46.

Akinsulie A.O, Temiye E.O, Akanmu A.S Lesi F.E.A, Whyte C.O (2005). Clinical Evaluation of Extract of Cajanus cajan (Ciklavit ${ }^{8}$ ) in Sickle Cell Anaemia Journal of Tropical Pediatrics, Volume 51, Issue 4, Pages 200-205,

Imaga, N.O.A. (2017). The use of phytomedicines as effective therapeutic agents in sickle cell anemia Scientific Research and Essays Vol. 5(24), pp. 38033807.

Fernandes, J. (2017). Plant Extracts Show Promise for Managing Sickle Cell Disease Symptoms, Study Says. Sickle cell Disease News. https://sicklecellanemianews.com/

Cordovil, K. (2015). Review of Medicinal Cajanus cajan of properties in Sickle Cell Disease. Rev. bras. plantas med. [online]. 2015, vol.17, n.4, suppl.3, pp.1199-1207. ISSN 1516-0572 